\title{
Listening to nature's voice: invasive species, Earth jurisprudence and compassionate conservation
}

\author{
Sophie Riley \\ Senior Lecturer, University of Technology Sydney
}

Humanity's land management practices reconstruct nature by destroying and degrading habitats, species and ecosystems, and creating environmental imbalance. The latter can manifest in overabundant or invasive species, imposing a welfare burden on unwanted animals when they are targeted for eradication and control. Such approaches not only overlook animal wellbeing, but also ignore the role that humans have played in species' classifications. As societies grapple to manage the unstable environments they have created, they have also started to realize that standards set by paradigms, such as sustainable development, do not sufficiently engage with the efficacy or ethics of existing practices. This article argues that a synthesis of law and science, drawn respectively from emerging paradigms, such as the Great Law of Earth jurisprudence and principles of compassionate conservation, can help guide environmental regimes towards more effective and ethical outcomes. From a legal perspective, the Great Law subordinates human law to a metaphorical nature's voice, while from a scientific perspective the scientific underpinnings of compassionate conservation identify that voice. Although compassionate conservation injects empathy into the decision-making processes, it is a form of empathy based on science that commences from the stipulation that regulators should first do no harm. It is a call that is specifically relevant to invasive species, where current regulation is based on harming certain species, while simultaneously overlooking environmental threats generated by humans. By using science to identify nature's voice, and law to listen to that voice, regulators can start to design regimes that work with nature, rather than trying to reconstruct and dominate it.

Keywords: Earth jurisprudence, rights of Mother Earth, compassionate conservation, invasive species

\section{INTRODUCTION}

Writing in 2013, Marc Bekoff described how humanity's land management practices have 'redecorated' nature by destroying and degrading habitats, species and ecosystems. ${ }^{1}$ These practices include land clearing as well as the control and eradication of wild animals and the management of overabundant species, pest species, invasive or

1. Marc Bekoff in Marc Bekoff (ed), Ignoring Nature No More: The Case for Compassionate Conservation (The University of Chicago Press, 2013) Preface, xiii, xix. 
invasive alien species (hereafter, collectively referred to as 'invasive species'). ${ }^{2}$ Such practices have been criticized for their 'subjective and anthropocentric nature', where killing unwanted species becomes the norm and 'humane treatment is often the first casualty'. ${ }^{3}$

Some commentators have critiqued these approaches for their lack of moral probity and tendencies towards domination of nature, trajectories that have not been averted by sustainable development, the predominant environmental paradigm. ${ }^{4}$ Yet, ethical insufficiency and domination of nature were far from key aims of sustainable development, which in its inception was constrained by socio-economic and environmental considerations. These were reflected in a vision of biodiversity protection based on intrinsic value, which was articulated in the preamble to the Convention on Biological Diversity, 1992 (CBD). ${ }^{5}$ This would have attributed value to biodiversity, irrespective of human needs, potentially containing anthropocentric ideals within broad moral parameters. ${ }^{6}$

At the same time, intrinsic value does not suggest that all parts of nature or biodiversity are created equal, or indeed, are equally valued. The CBD, for example, tacitly acknowledges that different categories of biodiversity warrant different levels of protection. Threatened species and degraded ecosystems merit special protection, ${ }^{7}$ while invasive alien species (IAS), those introduced species that threaten biodiversity, need to be eradicated and controlled. ${ }^{8}$ Furthermore, ascribing intrinsic value to species does not identify the locus of value, which could occur at the individual, population, species or ecosystem levels. It is an important issue, which determines the emphasis of regimes and whether administrators pay regard to animals in collectives, or as individuals.

The CBD categorises wildlife in collectives, at the species and population levels, implying that value is also located in the collective. ${ }^{9}$ As a general principle, this can be problematic in the design and implementation of environmental regimes for two

2. Susan M Sphectman, 'The "Bambi Syndrome:" How NEPA'S Public Participation in Wildlife Management is Hurting the Environment' (1977-78) 8 Environmental Law 611, 616; Daniel Ramp, Dror Ben-Ami, Keely Boom and David B Croft, 'A Paradigm Shift for Wildlife Management in Australia' in Bekoff (n 1) 295, 295.

3. Ramp et al (n 2) 298, quoting Graeme Caughley, 'Overpopulation' in PA Jewell, S Holt and D Hart (eds), Problems in the Management of Locally Abundant Wild Animals (Academic Press, 1981).

4. Val Plumwood, Environmental Culture: The Ecological Crisis of Reason (Routledge, 2002) 99-100; United Nations, 'Sustainable Development: Harmony with Nature, Report of the Secretary-General', A/66/302 para. 62, 66.

5. Nico Schrijver, The Evolution of Sustainable Development in International Law: Inception, Meaning and Status (Martinus Nijhoff, 2008), 218, quoting Patricia Birnie and Alan Boyle, International Law and the Environment (Oxford University Press, 2002) 45, 217; Convention on Biological Diversity 1992 (CBD) [1993] ATS no 32, preamble; the Convention opened for signature on 5 June 1992, and entered into force 29 December 1993. The Convention has 196 Parties.

6. David G Victor, Kal Raustiala and Eugene B Skolnikoff, 'Introduction and Overview' in David G Victor, Kal Raustiala and Eugene B Skolnikoff (eds), The Implementation and Effectiveness of International Environmental Commitments: Theory and Practice (MIT Press, 1998) 7; James Justus, Mark Colyvan, Helen Regan and Lynn Maguire, 'Buying into Conservation: Intrinsic versus Instrumental Value' (2009) 24(4) Trends in Ecology and Evolution 187, 187.

7. CBD, Articles 8(f), 8(k), 8(l).

8. CBD, Article $8(\mathrm{~h})$.

9. CBD, Article 2, definition of 'biological diversity', Articles 8(d), (f), (h) and (k). 
reasons: first, it does not sufficiently incorporate individual animal wellbeing; and, second, by focusing on species in the collective, it makes it easier to avoid difficult questions associated with human impacts on the environment. However, as with critiques of sustainable development, society has started to question the efficacy and ethics of these approaches. ${ }^{10}$ One part of the debate examines whether sustainable development is, itself, sufficiently robust to deal with ethical considerations. ${ }^{11}$ Another part examines whether emerging concepts, such as Earth jurisprudence and compassionate conservation, can provide frameworks for designing environmental regimes with greater efficacy and ethical integrity. ${ }^{12}$

The purpose of this article is to evaluate Earth jurisprudence and compassionate conservation, through the lens of invasive species regulation, in order to identify regulatory weaknesses and suggest improvements in the management of these species. Although the study focuses on invasive species, the analysis and general conclusions potentially apply to human-nature interactions at large. Invasive species have been selected for discussion because their regulation is ostensibly based on utilitarian balancing designed to protect biodiversity. Yet, in reality, regulation is frequently an attempt to deal with unsustainable land management practices. ${ }^{13}$ It is argued that this places an unanswered welfare burden on invasive species which are targeted for eradication and control, while far-reaching human activities, such as vegetation clearance and habitat destruction, mostly continue unchecked. ${ }^{14}$ In order to make the material manageable, the discussion focuses on Australia; however, the problems faced by Australia are analogous to problems in other jurisdictions, meaning that much of the discussion would also be relevant in these cases. ${ }^{15}$

The article commences by examining the problem of invasive species and their regulation in the context of sustainable development. It then moves to an evaluation

10. Michael Jacobs, 'Sustainable Development as a Contested Concept' in Andrew P Dobson (ed), Fairness and Futurity: Essays on Environmental Sustainability and Social Justice (Oxford University Press, 1999) 21, 31; Brian Preston, 'The Role of the Judiciary in Promoting Sustainable Development: The Experience of Asia and the Pacific' (2005-06) 9 Asia Pacific Journal of Environmental Law 109, 130-32.

11. Jacobs (n 10) 31; Preston (n 10) 130-32.

12. United Nations, 'Sustainable Development: Harmony with Nature', Report of the Secretary-General, A/71/266, Introduction.

13. Generally, Shelley Burgin, 'What about Biodiversity? Redefining Urban Sustainable Management to Incorporate Endemic Fauna with Particular Reference to Australia' (2016) 19 Urban Ecosystems 669; Daniel Ramp, 'Bringing Compassion to the Ethical Dilemma in Killing Kangaroos for Conservation, Comment on "Conservation Through Sustainable Use" by Rob Irvine' (2013) 10 Bioethical Inquiry 267, 267.

14. Sara Dubois, Nicole Fenwick, Erin A Ryan, Liv Baker, Sandra E Baker, Ngaio J Beausoleil, Scott Carter, Barbara Cartwright, Federico Costa, Chris Draper, John Griffin, Adam Grogan, Gregg Howald, Bidda Jones, Kate E Littin, Amanda T Lombard and David J Mellor, 'International Consensus Principles for Ethical Wildlife Control' (2017) 31(4) Conservation Biology, 753, 755.

15. These include problems with predators, invasive birds and invasive introduced species: Kate Rawles, 'Biological Diversity and Conservation Policy' in Markku Oksanen and Juhani Pietarinen (eds), Philosophy and Biodiversity (Cambridge University Press, 2004) 201, for ruddy ducks in the United Kingdom; Sandro Bertolino and Piero Genovesi, 'Spread and Attempted Eradication of the Grey Squirrel (Sciurus carolinensis) in Italy and Consequences for the Red Squirrel' (2003) 109 Biological Conservation 351, 351, 356; Arian D Wallach, Euan G Ritchie, John Read, Adam J O’Neill, 'More than Mere Numbers: The Impact of Lethal Control on the Social Stability of a Top-Order Predator' (2009) Public Library of Science One, https://doi.org/10.1371/journal.pone.0006861. 
of the significance of Earth jurisprudence and compassionate conservation with their calls respectively, in a metaphorical sense, to listen to 'nature's voice' and 'do no harm'. ${ }^{16}$ Part of the analysis involves reviewing provisions in the CBD and the Guiding Principles for the Prevention, Introduction and Mitigation of Impacts of Alien Species that Threaten Ecosystems, Habitats or Species (Guiding Principles) for their ethical consistency. ${ }^{17}$ Although the Guiding Principles note that measures should be 'environmentally benign' and 'ethically acceptable' to stakeholders, ${ }^{18}$ these initiatives fall short of the scientific and ethical dimensions that underpin Earth jurisprudence and compassionate conservation. ${ }^{19}$ It is concluded that society needs a fresh approach where humans take responsibility for their 'redecoration' of nature by designing and implementing holistic regimes that are consistent with principles drawn and synthesized from Earth jurisprudence and compassionate conservation.

\section{THE PROBLEM OF INVASIVE SPECIES AND THEIR REGULATION}

The CBD uses the phrase 'invasive alien species' to describe species that have been 'introduced outside [their] ... natural past or present distribution' and which 'threaten biological diversity'. ${ }^{20}$ Biodiversity protection is also part of the rubric of sustainable development, and accordingly Article 8(h) of the CBD provides that States are under obligation to prevent the entry of invasive alien species, as well as eradicate and control them. Sustainable development itself is defined as development that does not compromise the ability of future generations to meet their own needs. ${ }^{21}$ In recognition of the fact that development can lead to the introduction of invasive species, and undermine objectives of sustainability, the Guiding Principles identify links between development and invasive species, including, trade, transportation, tourism and the effects of climate change. ${ }^{22}$ Deliberate and accidental introductions, for example, frequently occur as a result of inadequate identification, evaluation and management of

16. Begonia Filgueira and Ian Mason, 'Wild Law: Is there Any Evidence of Earth Jurisprudence in Existing Law?' in Peter Burdon (ed), Exploring Wild Law: The Philosophy of Earth Jurisprudence (Wakefield Press, 2011) 192, 198; Daniel Ramp and Marc Bekoff, 'Compassion as a Practical and Evolved Ethic for Conservation' (2015) 65 (3) Bioscience, 323, 325.

17. CBD, Article 8(h); Guiding Principles for the Prevention, Introduction and Mitigation of Impacts of Alien Species that Threaten Ecosystems, Habitats or Species, Guiding Principles 2, 7 and 10. Adopted April 2002 as part of Decision VI/23 of the Conference of the Parties. Report of the Sixth Meeting of the Conference of the Parties to the Convention on Biological Diversity, UNEP/CBD/COP/6/20 (23 September 2002. Other treaty systems such as the International Plant Protection Convention and the World Organisation for Animal Health, (the OIE) deal with pests and diseases of plants and animals, but the CBD is the primary instrument regulating IAS of biodiversity at large.

18. Guiding Principles, Guiding Principle 12, Preamble para. 24.

19. Convention on Biological Diversity, Conference of the Parties, thirteenth meeting Cancun, Mexico, 4-17 December 2016, Item 2 of the provisional agenda 'Living in Harmony with Nature', paras 18-20, UNEP/CBD/COP/13/9, 4 October 2016, available from www.cbd.int/doc/meetings/ cop/cop-13/official/cop-13-09-en.pdf, accessed 18 March 2019.

20. CBD Guiding Principles, definitions in footnote 57.

21. Gro Harlem Brundtland, Report of the World Commission on Environment and Development: Our Common Future, transmitted to the General Assembly as an Annex to UN Doc A/42/427 Part 2.1 (1987), Chapter 3, II, para. 8.

22. CBD Guiding Principles, Preamble, para. 1. 
environmental risks in the trade of ornamental plants, aquarium pets, cut flowers and pasture grasses. ${ }^{23}$ What is more, human activities relating to agriculture, and resource management, can create ecosystem imbalance, contributing to invasiveness or overabundance of alien, as well as, native species. ${ }^{24}$

Much has been written on the impacts of invasive species, from threats to biodiversity to economic consequences in agricultural systems. ${ }^{25}$ The CBD concludes that:

[i]nvasive alien species have invaded and affected native biota in almost every ecosystem type on Earth, and have affected all major taxonomic groups. In economic terms, the costs of invasive alien species are significant. Total annual costs, including losses to crops, pastures and forests, as well as environmental damages and control costs, have been conservatively estimated to be in the hundreds of billions of dollars and possibly more than one trillion. This does not include valuation of species' extinctions, losses in biodiversity, ecosystem services and aesthetics. ${ }^{26}$

For these reasons, the CBD obliges States to manage invasive alien species. Significantly, it is the categorisation of species as invasive, rather than alien, which acts as the trigger for measures. This is a clear consequence of obligations deriving from Article 8(h) that are based on alien species that threaten ecosystems, habitats or other species. As already noted, Article 8(h) is also supplemented by the Guiding Principles that detail how to make the Article operational. They initiate a twofold focus, starting with preventing introductions across international boundaries, and

23. Alexandra Zieritz, Belinda Gallardo, Simon J Baker, J Robert Britton, Johan L C H van Valkenburg, Hugo Verreycken and David C Aldridge, 'Changes in Pathways and Vectors of Biological Invasions in Northwest Europe' (2017) 19 Biological Invasions 269, 270, 279; Sophie Riley, 'Using "Threatening Processes" To Protect Freshwater Biodiversity From Invasive Alien Species' (2012) 1 Canberra Law Review 58, 59, 61-63; generally, Don A Driscoll, Jane A Catforda, Jacob N Barney, Philip E Hulme, Inderjit, Tara G. Martina, Aníbal Pauchardi, Petr Pyšekk, David M Richardson, Sophie Riley and Vernon Visser, 'New Pasture Plants Intensify Invasive Species Risk' (2014) 111(46) Proceedings of the National Academy of Sciences of the United States of America 1, www.pnas.org/content/early/2014/10/29/1409347111, accessed 18 March 2019.

24. Tim Low, Feral Future (Viking, 1999) Chapters 11 and 23; Tasmania, Department of Primary Industries, Parks, Water and Environment, Wildlife Management Branch, Plan for the Commercial Harvest and Export of Brushtail Possums in Tasmania 2010-2015, (2010), at 6, available at www.environment.gov.au/biodiversity/wildlife-trade/publications/ mgt-plan-commercial-harvest-export-brushtail-possums-tas-2015-2020, accessed 18 March 2019. 25. For example, Ted Center, J Howard Frank, and Allen F Dray, 'Biological Invasions: Stemming the Tide in Florida' (1995) 78(1) Florida Entomologist 45; Steve L Coles and L Eldredge, 'Nonindigenous Species Introductions on Coral Reefs: A Need for Information' (2002) 56 Pacific Science 191; Lyle Glowka, 'Bioprospecting, Alien Invasive Species, and Hydrothermal Vents: Three Emerging Legal Issues in the Conservation and Sustainable Use of Biodiversity' (2000) 13 Tulane Environmental Law Journal 329; T McDowell, 'SlowMotion Explosion: The Global Threat of Exotic Species and the International Response to the Problem in the South Pacific' (1998) 9 Colorado Journal Of Environmental Law And Policy 187; Jeffrey A McNeely, 'Invasive Species: a Costly Catastrophe for Native Biodiversity' (2002) 1(2) Land Use And Water Resources Research 1; Marc Miller, 'Biological and Cultural Camouflage: The Challenges of Seeing the Harmful Invasive Species Problem and Doing Something About It' in Marc Miller and R Fabian (eds), Harmful Invasive Species: Legal Responses (Environmental Law Institute, 2004).

26. Convention on Biological Diversity, Information Sheet, 'Why Does it Matter', www.cbd. int/invasive/matter.shtml, accessed 18 March 2019. 
then implementing mitigation measures, by way of eradication and control, at the national level. ${ }^{27}$ This means that regulators need to make decisions identifying environmental threats and also the types of measures required to manage those threats. Against this backdrop, justification for eradication and control reaches beyond the ambit of Article 8(h) to include killing overabundant native species in order to ensure survival of their populations, as well as killing native and introduced species to prevent their interfering with human activities. ${ }^{28}$

Underpinning these decisions, lie value choices concerning what is worthy of protection. If it is kept in mind that not all biodiversity is protected to the same extent, and that some species will be earmarked for eradication, this raises a number of ethical issues that are not adequately addressed within the CBD. In particular, these developments cast doubt on whether regimes are 'ethically acceptable' to stakeholders and are 'environmentally benign', two concepts mentioned in the Guiding Principles as relevant to invasive species' regimes. ${ }^{29}$

In Australia, regulation comprises a mix of legislation, guidelines, management plans and codes of conduct. This includes declaring a species a pest, ${ }^{30}$ listing the impacts of animals as a threatening process and/or the implementation of management plans to reduce populations below a threshold considered harmful. ${ }^{31}$ What is more, management invariably comprises lethal methods. ${ }^{32}$ At first glance, regimes appear comprehensive, but in reality, they can engender priorities which focus on reducing numbers of species, rather than dealing with the underlying reasons why species become invasive. ${ }^{33}$ This not only raises ethical considerations inherent in choosing lethal measures, but it also means that regimes may not be effective in

27. Guiding Principle 4, for example promotes the Ecosystem Approach, focussing on international obligations to minimize introductions across international boundaries, while Guiding Principles; Guiding Principle 15 focusses on reducing numbers of IAS, as well as the damage caused by them.

28. This includes species such as bats and possums: Carol Booth, Kerryn Parry-Jones, Nicola Beynon, Nancy Pallin, Bob James et al, Why NSW should Ban the Shooting of Flying-Foxes for Crop Protection (2008) Published by a network of biologists, conservationists and wildlife carers with major contributions by those names as authors, available from www.environment. nsw.gov.au/resources/animals/flying-fox-2014-subs/flyingfoxsub-robyn-hittmann-part2.pdf, accessed 18 March 2019; Michael Condon, 'New South Wales Bat Cull Could Start this Week, but Vets Warn it Won't Work' ABC Rural (27 October 2014) available from www.abc.net.au/ news/2014-10-27/nrn-nsw-bat-cull-warning-27-10-14/5843570, accessed 18 March 2019; Tasmania, Department of Primary Industries, Parks, Water and Environment, Wildlife Management Branch, Plan for the Commercial Harvest and Export of Brushtail Possums in Tasmania 2010-2015 (n 24) 6.

29. Guiding Principles, Guiding Principle 12, Preamble para. 24.

30. For example, Local Land Services Act 2013 (NSW), ss 130 and 142.

31. In New South Wales, for example, threatening processes are set out in Schedule 4 of the Biodiversity Protection Act 2016 (NSW) and made in accordance with s 4.33; Office of Environment and Heritage, New South Wales Commercial Kangaroo Harvest Management Plan 2012-2016, Office of Environment and Heritage, Department of Premier and Cabinet (NSW), Sydney (2011); NSW Office of Environment and Heritage, Management Plan for Cane Toads in National Parks and Reserves, State of New South Wales (2012), available from www.environment.nsw.gov.au/ resources/pestsweeds/13772canetdmp.pdf, accessed 18 March 2019.

32. Generally, Sophie Riley, 'Model Codes for the Humane Treatment of Animals: Australian Law and Policy on Lethal Control of Pests' (2015) 18(4) Journal of International Wildlife Law and Policy 276.

33. Ibid, 283-86. 
the long term. ${ }^{34}$ To be effective requires extending the regulatory focus away from individual species and towards human-wildlife interactions in order to manage the causes, rather than the symptoms of invasiveness. To do otherwise shifts the accountability burden towards wildlife and away from human activities that destroy habitat, fragment forests and degrade biodiversity. ${ }^{35}$

Urbanisation is a case in point. At present, approximately one-half of the world's population live in urban areas and it is anticipated that this will increase to ' 70 per cent by 2050 '. ${ }^{36}$ When humans gravitate towards urban areas, forests and vegetation are cleared for development and sometimes re-vegetated, upsetting the original mix of species. Particularly profound changes occur with reduction of density and variety of avian species because clearing fosters colonization by large birds and introduced species and the depletion of small native birds. ${ }^{37}$ In Australia, these tendencies are exacerbated by re-planting with popular native cultivars such as bottle brushes and grevilleas and/or feeding native birds which may also encourage populations of larger, aggressive birds. ${ }^{38}$ In such cases, bird numbers do not 'explode' but respond to increased availability of resources, and similarly, bird numbers will abate in response to limiting resources. ${ }^{39}$ The most common birds found after clearing and re-planting are rock doves and rainbow lorikeets and in areas at the periphery of cleared sites, noisy miners and crows. ${ }^{40}$ The converse has also been observed, so that non-cleared areas support a higher number of birds, as well as higher numbers of koalas, possums and gliders. ${ }^{41}$

Disturbed landscapes can also act as a source for colonizing surrounding areas and can alter connectivity of landscapes and ecosystems by enabling or hindering the migration of species. ${ }^{42}$ In addition, changing the mix of vegetation can alter species

34. Graeme Caughley and Anthony RE Sinclair, Wildlife Ecology and Management (Blackwell Science, 1994) Chapter 17, paras 17.3-17.5, 17.7; Riley (n 32) 278, 282.

35. Robert J Fuller, 'Relationships between Recent Changes in Lowland British Agriculture and Farmland Bird Populations: an Overview' in NJ Aebischer, AD Evans, PV Grice and JA Vickery (eds), Ecology and Conservation of Lowland Farmland Birds (Proceedings of the 1999 British Ornithologists Union Spring Conference, University of Southampton, 27-28 March 1999, British Ornithologists Union, Tring, 2000) 12; generally, Driscoll et al (n 23); Low (n 24) Ch 11; Stuart Harrop, '2010 Nagoya Conference of the Convention on Biological Diversity' (2011) 23(1) Journal of Environmental Law 117, 118.

36. Burgin (n 13) 669.

37. Ronda J Green and Carla P Catterall, 'The Effects of Forest Clearing and Regeneration on the Fauna of Wivenhoe Park, South-East Queensland' (1998) 25 Wildlife Research, 677, 681; Carla Catterall, 'Birds, Garden Plants and Suburban Bushlots: Where Good Intentions Meet Unexpected Outcomes' in Shelley Burgin and Daniel Lunney (eds), Urban Wildlife: More than Meets the Eye (Royal Zoological Society of NSW, 2004) 5, available from https:// research-repository.griffith.edu.au/bitstream/handle/10072/415/28838_1.pdf?sequence=2\&is Allowed=y, accessed 18 March 2019; Lucy Taylor, Charlotte Taylor and Adrian Davis, 'The Impact of Urbanisation on Avian Species: The Inextricable Link between People and Birds' (2013) 16 Urban Ecosystems 481, 481.

38. Burgin (n 13) 669, 672.

39. Ibid, 674 .

40. Ibid, 671; Lucy Taylor et al (n 37) 491; Green and Catterall (n 37) 681.

41. Green and Catterall (n 37) 682.

42. Amanda D Rodewald and Peter Arcese, 'Direct and Indirect Interactions between Landscape Structure and Invasive or Overabundant Species' (2016) 1 Current Landscape Ecology Reports 30, 31. 
interactions, making degraded ecosystems more susceptible to invasion. ${ }^{43}$ This, in fact, is precisely what has occurred in the case of overabundant bell miners in New South Wales. Land management practices have created habitat that not only promotes the establishment of bell miners, but also supports increased numbers of psyllids, a small insect that feeds on tree sap and is implicated in eucalyptus die-back. ${ }^{44}$ In a flow-on effect, habitat which favours bell miners will preclude other insect-eating birds, further increasing numbers of psyllids and accelerating eucalyptus dieback. ${ }^{45}$ Similar problems have occurred in the case of overabundant noisy miners, where clearing low-lying shrubs favours increased populations of these birds, leading to the decline of smaller birds, such as wrens. ${ }^{46}$

In an attempt to manage excess bell miners and noisy miners, authorities have used environmental legislation to list their overabundance as a threatening process. ${ }^{47}$ This acts as tacit acceptance that the presence of these birds results in significant ecological disturbance which must be mitigated by eradication and control measures. However, research demonstrates that combinations of human-induced events are likely to have greater detrimental impacts on ecosystems. ${ }^{48}$ In the case of eucalyptus die-back for example, land clearing and fragmentation, logging, fire and grazing regimes, weed management, pathogens and hydrological factors are more important agents of environmental degradation than abundance of bell miners. ${ }^{49}$

From an ethical perspective, the philosophy which guides invasive species regimes is based on utilitarianism, a form of consequentialism that judges the morality of actions by their outcomes. The killing of noisy miners and bell miners is, therefore, justified where it results in increased populations of small birds, or reduction in eucalyptus die-back, as long as certain safeguards are employed that, as far as possible, take into account the welfare of noisy miners and bell miners. Yet, regulators avoid grappling with human-induced degradation, while simultaneously seeing solutions in terms of killing species that have taken advantage of the environment created by humans. ${ }^{50}$ It is also an approach that does not adequately take into account the individual welfare burden placed on targeted species, a standpoint that is closely aligned to control and domination of nature..$^{51}$

43. Ibid.

44. Grant Wardell-Johnson and A Jasmyn J Lynch, 'Landscape Processes and Eucalypt Dieback Associated with Bell Miner Habitat in Southeastern Australia' (2005) 68(4) Australian Forestry $242,247$.

45. Ibid.

46. NSW Scientific Committee, Final determination, 'Aggressive Exclusion of Birds from Woodland and Forest Habitat by Abundant Noisy Miners Manorina melanocephala (Latham 1802)', (2013), para. 2 available from www.environment.nsw.gov.au/resources/threatened species/FDNoisminerKTP.pdf, accessed 18 March 2019.

47. Ibid; NSW Scientific Committee, Final determination, 'Forest Eucalypt Dieback Associated with Over-abundant Psyllids and Bell Miners - Key Threatening Process Listing' (2008) paras 4-5, available from www.environment.nsw.gov.au/determinations/bellminerfd. htm, accessed 18 March 2019.

48. Wardell-Johnson and Lynch (n 44) 242.

49. Ibid, 242-46.

50. Tim Low, The New Nature, Winners and Losers in Wild Australia (Penguin, 2003) 21 and Chapter 8.

51. Gwendellyn Io Earnshaw, 'Equity as a Paradigm for Sustainability: Evolving the Process toward Interspecies Equity' (1999) 5 Animal Law 113, 116. 
Similar arguments apply to other areas, such as agricultural regions. In Australia, rangelands extend across 75 percent of the country and have been significantly altered by livestock grazing. ${ }^{52}$ This has led to clashes among stakeholders resulting in the killing of an array of animals, including, kangaroos, wombats, dingoes and cockatoos, in order to safeguard agriculture and livestock production. ${ }^{53}$ Consequently, regulators have started relaxing the need for specific licences to kill birds, including cockatoos and magpies, as well as promoting commercial hunting, by way of 'consumptive use', for animals such as kangaroos. ${ }^{54}$ In some cases, the latter has been economically successful, but if used as a conservation tool it raises issues similar to those raised by management of noisy miners and bell miners: more specifically, whether eradication and control represent attempts to remedy ineffective land management. ${ }^{55}$ In addition, the wellbeing of targeted animals invariably receives insufficient attention. ${ }^{56}$ By way of illustration, the debate surrounding commercial harvesting of kangaroos indicates that regulators have considered the effectiveness of the regime itself, but have not adequately dealt with welfare considerations. ${ }^{57}$

Approaches which evince insufficient regard for ethical concerns can lead to public disengagement and hostility, potentially undermining regimes. Lack of ethical engagement and public opposition, for example, have been identified as significant reasons for controversy surrounding eradication programmes, such as horse culling in Mount Kosciusko national park in Australia. ${ }^{58}$ This is perhaps not surprising as horse culls involve aerial shooting, with questionable welfare outcomes, of an animal immortalised in Australian culture. ${ }^{59}$ Given the unpopularity of this proposal, protests by members of the Australian public led to the abandonment of aerial horse culls and then to the protection of wild horses for cultural reasons. ${ }^{60}$ These matters can be

52. Ramp (n 13) 267.

53. Discussion surrounding $\mathrm{n} 57$ below.

54. Ramp (n 13) 267; Office of Environment and Heritage, New South Wales Commercial Kangaroo Harvest Management Plan 2012-2016 (n 31); NSW Office of Environment and Heritage, Management Plan for Cane Toads in National Parks and Reserves, State of New South Wales (2012) (n 31); NSW Department of Environment and Conservation, Deer Management Plan 2005-2008 for Royal National Park and NPWS Parks and Reserves in the Sydney South Region, NSW Department of Environment (2005) (n 31).

55. Ramp (n 13) 268.

56. Generally, Keely Boom, Dror Ben Ami, Louise Boronyak and Sophie Riley, 'The Role of Inspections in the Commercial Kangaroo Industry' Occasional Papers (2013) International Journal of Rural Law and Policy 162.

57. Ibid; Daniel Ramp (n 13) 269; Harriet Aird, 'Wombat Cull Permit Rules "Tightened", as Calls Grow to Halt "Insanity" of Legal Kills' $A B C$ News (14 June 2017), available from www. abc.net.au/news/2017-06-14/wombat-kill-permits-tightened-amid-warnings-of-tas-tiger-debacle/ 8616154, accessed 18 March 2019; Stephanie Smail, 'More Cockatoos, Wallabies and Possums Culled at Hamilton Island Resort' ABC News (20 December 2016) www.abc.net.au/news/201612-20/more-wildlife-cull-hamilton-island-resort-rspca-steven-miles/8133396, accessed 18 March 2019; Booth et al (n 28); generally, Boomet al (n 56); generally, Brad Vincent Purcell, Andrew Glover, Robert Claude Mulley and Robert Lachlan Close, 'Euro-Australian Culture and Dilemmas within the Science and Management of the Dingo, Canis lupus dingo' in Peter Banks, Daniel Lunney and Chris Dickman (eds), Science Under Siege: Zoology under Threat (Royal Zoological Society of NSW, 2012) 114.

58. Rawles (n 15) 201.

59. Ibid.

60. Ian Rotherham, 'Eco-xenophobia - Responding to our Natural Aliens' (2010) 31 (1) ECOS 2, 9; Peter Hannam, 'Brumbies Cull: Battle Over Wild Horses in Kosciusko National Park Heats Up' 
viewed on several levels, from a failure of animal welfare systems, to the wider perspective of humanity's discordant relationship with the environment. At their core, however, they provide examples that justify calls for new approaches.

\section{NEW APPROACHES: EARTH JURISPRUDENCE AND COMPASSIONATE CONSERVATION}

Two emerging approaches, Earth jurisprudence based on legal precepts and compassionate conservation based on science, are particularly relevant in the management of invasive species. They provide complementary approaches, which contribute essential elements to reconfiguring society's interactions with nature.

\subsection{Earth jurisprudence and the Great Law}

Earth jurisprudence draws on the work of Thomas Berry, who was a Catholic priest and environmentalist. The catalyst for Berry's views was condemnation of economic and anthropocentric ideals, which Berry regarded as a pernicious influence that would invariably lead to environmental degradation. ${ }^{61}$ Berry, therefore, called for new perspectives, set out in his book the Great Work: Our Way into the Future (the Great Work), which would transform humanity's relationship with the Earth from one of exploitation to one that is 'mutually beneficent'. ${ }^{62}$ A cornerstone of the Great Work derives from Berry's arguments that humans comprise only one part of Earth's community and accordingly do not sit at the apex of an Earth hierarchy. ${ }^{63}$ Rather, all living and non-living entities have vital and interdependent roles to play. ${ }^{64}$

Berry's philosophies have been adopted within concepts such as wild law, and find their most detailed expression in the notion of Earth jurisprudence. ${ }^{65}$ Although assigning a definition to Earth jurisprudence is as elusive as pinning down the concept of jurisprudence itself, Filgueira and Mason describe Earth jurisprudence as 'the philosophy of law and regulation that gives formal recognition to the reciprocal relationship between humans and the rest of nature'. ${ }^{66}$ This definition captures the essence

Sydney Moring Herald (11 June 2017) available from www.smh.com.au/environment/brumbiescull-battle-over-wild-horses-in-kosciusko-national-park-heats-up-20170609-gwnyob.html, accessed 18 March 2019; for attitudes on horse culling generally, Dale G Nimmo, Kelly K Miller and Robyn Adams, 'Managing Feral Horses in Victoria: A Study of Community Attitudes and Perceptions' (2007) 8(3) Ecological Management and Restoration 237, 239-40; Kosciusko Wild Horse Heritage Act 2018 (NSW), s 4 states that the object of the legislation is to 'recognise the heritage value of sustainable wild horse populations within parts of Kosciuszko National Park and to protect that heritage'.

61. Thomas Berry, The Great Work: Our Way into the Future (Three Rivers Press, 1999) 132-35.

62. Berry, ibid, 3; Jules Cashford, 'Dedication to Thomas Berry' in Peter Burdon (ed), Exploring Wild Law: The Philosophy of Earth Jurisprudence (Wakefield Press, 2011) 3, 5; Michelle Maloney, 'Earth Jurisprudence and Sustainable Consumption' (2011) 14 Southern Cross University Law Review 119, 119.

63. Berry (n 61) 3-5; Ian Mason, 'One In All: Principles and Characteristics of Earth Jurisprudence' in Burdon (n 62) 35, 36.

64. Berry (n 61) 3-5; Mason (n 63) 35, 36.

65. Cormac Cullinan, 'A History of Wild Law' in Burdon (n 62) 12, 12-13, 19.

66. Generally, RHS Tur, 'What is Jurisprudence' (1978) 28(111) The Philosophical Quarterly 149; Filgueira and Mason (n 16) 195. 
of Berry's views, which, as just indicated, are based on the interconnectedness of life on Earth and moral obligations in that regard. ${ }^{67}$ It is an outlook that stands in contrast to human law that is grounded in anthropocentrism and positivism, where social mores and ethical probity barely rate a mention. ${ }^{68}$

In accordance with Berry's views, Earth jurisprudence subordinates human law to the authority of the 'Great Law' (also referred to as the Great Jurisprudence). ${ }^{69}$ The Great Law and human law thus sit in a hierarchical relationship where human law depends on the Great Law and also needs to be consistent with it. ${ }^{70}$ Yet, the content of the Great Law is not settled. For some, the universe and the laws of nature can be seen as a source of the Great Law because the universe determines key criteria upon which all life depends, such as, 'time scales, life spans, seasons and temperature ranges'. ${ }^{71}$ For others, however, references to the 'laws of nature' are too broad and vague to form the basis of policy and regulation. ${ }^{72}$ Burdon describes the Great Law as representing 'the rules or principles of nature, which are discoverable by human beings and relevant to human-earth interaction' ${ }^{73}$ Accordingly, the Great Law would comprise key ecological principles that remain central and constant, such as the interconnectedness of the web of life. ${ }^{74}$ Determining what these principles are, and their relative importance to law and policy, requires drawing science and law together, an issue discussed further in part four of this article.

Although the content of the Great Law is still evolving, Earth jurisprudence has been elaborated in terms of 'rights' of the Earth community, which supersede human law:

- The Earth community and all the beings that constitute it have fundamental 'rights', including the right to exist, to inhabit or a place to be, and to participate in the evolution of the Earth community.

- The rights of each being are limited by the rights of other beings to the extent necessary to maintain the integrity, balance and health of the communities within which it exists.

- Human acts or laws that infringe these fundamental rights violate the fundamental relationships and principles that constitute the earth community ("the Great Jurisprudence') and are consequently illegitimate and 'unlawful'.

- Humans must adapt their legal, political, economic and social systems to be consistent with the Great Jurisprudence and to guide humans to live in accordance with it, which means that human governances systems at all times take account of the interests of the whole Earth community and must...

- recognise all members of the Earth community as subjects before the law, with the right to the protection of the law and to an effective remedy for human acts that violate their fundamental rights. ${ }^{75}$

67. Peter Burdon, 'A Theory of Earth Jurisprudence' (2012) 37 Australian Journal of Legal Philosophy 28, 30; Maloney (n 62) 119; United Nations, Sustainable Development, Harmony with Nature, Report of the Secretary- General, A/69/322, paras 3 and 4; United Nations, Sustainable development: Harmony with Nature, Report of the Secretary- General, A/71/266, para. 21.

68. Peter Burdon, 'The Great Jurisprudence' in Peter Burdon (n 62) 59, 59-60.

69. Cullinan (n 65) 13.

70. Burdon (n 68) 59, 61.

71. Filgueira and Mason (n 16) 194.

72. Burdon (n 68) 66.

73. Ibid, 60 .

74. Ibid, 66.

75. Cullinan (n 65) 13. 
These rights are designed to allow life on Earth to exist and fulfil its evolutionary role, ${ }^{76}$ but are also 'role-specific or species-specific', attaching in different ways to different entities and Earth components. ${ }^{77}$ Hence, the rights of trees would be specific to trees and would also differ from the rights of rivers, which again would be different from the rights of birds and the rights of mammals. ${ }^{78}$ One common feature, however, is that these rights originate from the very existence of entities or components, rather than from rights conferred by humans. ${ }^{79}$

As with Earth jurisprudence itself, the scope, ambit and content of these rights are still developing. From one perspective the use of rights terminology represents a means of making Berry's ideals operational, and indeed Berry himself spoke of rights. ${ }^{80}$ However, Berry did not fully embrace the legal and policy standpoints inherent in a jurisprudential approach. He had particular reservations concerning the use of legal rights language where it was devoid of ethical considerations, fearing it might not be the best way of promoting the Great Work. ${ }^{81}$ In addition, while he theoretically saw the law as an instrument of positive change, he also saw it as an instrument of complicity, capable of maintaining an unjustifiable status quo. ${ }^{82}$ Nevertheless, Berry was sufficiently realistic to concede that legal rights represented the most feasible way forward. He ultimately regarded law and morality as being interwoven, potentially allowing each to compensate for the other's weaknesses. ${ }^{83}$

One open question concerns the locus of rights proffered by Earth jurisprudence, whether this lies at the collective or individual level. This is an important issue, particularly in the regulation of invasive species, because the welfare of these species needs to be considered at an individual level. ${ }^{84}$ Earth jurisprudence clearly envisages that collectives have rights, consisting of rights to participate in the Earth community and to evolve. Individual rights comprise rights that 'all members' of the Earth community have to seek redress for 'human acts that violate their fundamental rights' ${ }^{85}$ At the same time, individual rights 'are limited by the rights of other beings to the extent necessary to maintain the integrity' of the Earth community. These provisions are similar to Articles found in the Universal Declaration of Rights of Mother Earth, adopted at the World People's Conference on Climate Change and the Rights of Mother Earth, held in Cochabamba 2010 (Universal Declaration). ${ }^{86}$

76. Maloney (n 62) 140.

77. Cashford (n 62) 3, 9 .

78. Ibid.

79. United Nations, Sustainable Development, Harmony with Nature, Report of the SecretaryGeneral, A/68/325, paras 16-17; United Nations, Sustainable Development, Harmony with Nature, Report of the Secretary General, A/69/322, para. 22.

80. Berry (n 61) 4-5.

81. Cashford (n 62) 3, 5 .

82. Ibid.

83. Ibid, $3,5,8$.

84. For example, Peter Singer's views clearly conceptualize welfare as applying at an individual level, Peter Singer, 'All Animals are Equal' in Michael Zimmerman (ed et al) Environmental Philosophy, From Animal Rights to Radical Ecology (Prentice Hall, 2001) 26, 28 and 30; Peter Singer, Animal Liberation (Harper-Collins, 2009) 5, 20-21.

85. Cullinan (n 65) 13.

86. Universal Declaration of Rights of Mother Earth, Articles 1(2), 1(3) and 1(4), available from http://therightsofnature.org/wp-content/uploads/FINAL-UNIVERSAL-DECLARATIONOF-THE-RIGHTS-OF-MOTHER-EARTH-APRIL-22-2010.pdf, accessed 18 March 2019. 
Article 2(3) of the Universal Declaration provides that animals have individual rights against torture or cruel treatment by humans; while Article 1(7) states that the 'rights of each being are limited by the rights of other beings and any conflict between their rights must be resolved in a way that maintains the integrity, balance and health of Mother Earth'. The rights afforded under Article 2(3) are, therefore, analogous to provisions in Earth jurisprudence that proscribe 'human acts that violate' other's rights. Although Earth jurisprudence does not specifically identify that individual animals are a beneficiary of this proscription, it also does not exclude individuals from this sphere of rights. However, given that both the Universal Declaration and Earth jurisprudence limit the rights of beings and entities by the rights of other beings and entities, the application of these principles to individual animals seems akin to animal welfare provisions found in national jurisdictions that proscribe cruel treatment, unnecessary harm and suffering. ${ }^{87}$

If in fact this is the case, one difficulty deriving from the 'rights' language used by the Universal Declaration and Earth jurisprudence, stems from the weak design and application of national welfare regulation, which is frequently attenuated by qualifications as to what is necessary, unnecessary or acceptable. ${ }^{88}$ Such qualifications can, and do, lead to poor welfare outcomes. ${ }^{89}$ Moreover, although Article 1 of the Universal Declaration is drafted in 'rights' language, it also diminishes the power of individual rights by providing that the rights of Mother Earth override other rights. This is justified on the basis that animals and other living beings are an indivisible and interrelated part of Mother Earth. ${ }^{90}$ In this respect, Article 1 is very similar to key tenets of Earth jurisprudence that focus on the interconnectedness and integrity of life on Earth, and leave the issue of individual versus collective rights, very much open to debate.

Maloney and Cashford argue that if entities such as species and populations enjoy rights, then this extends to individuals because species and populations consist of individuals. ${ }^{91}$ Burdon has similarly argued that because Earth jurisprudence recognizes the intrinsic value of nature, law should impose obligations on humans that enable the rights of 'every being ... to be recognized and revered' ${ }^{92}$

Yet, others question whether Earth jurisprudence can extend this far. ${ }^{93}$ It is not, therefore, clear how Earth jurisprudence would manage the interplay between rights and welfare. If rights were to accrue only to the collective, this is analogous to the approach taken by sustainable development, which also locates value in the collective.

87. Robert Heeger and Frans WA Brom, 'Intrinsic Value and Direct Duties: From Animal Ethics towards Environmental Ethics?' (2001) 14(2) Journal of Agricultural and Environmental Ethics 241, 242.

88. Steven White, 'Into the Void: International Law and the Protection of Animal Welfare' (2013) 4(4) Global Policy 391, 391-93; Generally, Arnja Dalle, 'Animal Welfare Codes and Regulations - The Devil in Disguise?' in Peter Sankoff and Steven White (eds), Animal Law in Australasia (The Federation Press, 2009) 174; M Sherley, 'Is Sodium Fluoroacetate (1080) a Humane Poison?' (2007) 16 Animal Welfare 449, 449 and 454; Dominique Thiriet, 'Flying Fox Conservation Laws, Policies and Practices in Australia - A Case Study in Conserving Unpopular Species' (2010) 13(2) The Australasian Journal of Natural Resources Law and Policy 161, 163-65, 180-84.

89. Ibid.

90. Universal Declaration of Rights of Mother Earth, Articles 1(2)-1(4), 1(7).

91. Maloney (n 62) 140; Cashford (n 62) 3, 9.

92. Peter Burdon, 'Wild Law - The Philosophy of Earth Jurisprudence' (2010) 35 Alternative

Law Journal 62, 64.

93. Ibid. 
Consistent with that position, it is difficult to see what true rights animals would have, as opposed to welfare obligations that target human behaviour. Moreover, given that the Great Law subordinates human law, the relationship among differing rights per se, the value of the collective and the value of the individual will need to be refined and settled. At present, human law with respect to individual animals is based on welfare, a utilitarian balancing that is subject to many qualifications, which are not necessarily consistent with the Great Law. ${ }^{94}$ This is an unsettled area that will undoubtedly receive further attention as the concept of Earth jurisprudence evolves and develops.

At the same time, the fact that Earth jurisprudence discourse is framed in legal terminology does not mean that solutions are delineated by legal precepts. Science, for example, is vital to resolving environmental problems, including those that raise legal and ethical issues. Science can provide details on the nature of environmental problems and the consequences of interventions. More specifically, it can detect nature's voice, and thus help identify the content of the Great Law.

\subsection{Compassionate conservation}

Compassionate conservation evolved out of concern that conservation efforts frequently involve an 'entanglement of harm and care', ${ }^{95}$ normalizing views that conservation necessitates harming some animals, in order to save others, or, killing animals to protect the environment at large. ${ }^{96}$ This may include killing individuals from one species to protect another species, or killing individuals within the same species to protect the collective. ${ }^{97}$

Compassionate conservation challenges these approaches, instead calling for regimes to be based on 'empathy ... for nonhuman animals' ${ }^{98}$ As indicated in the introduction to this article, empathy in this instance is based on science, not emotion. At the same time, it is a version of science that takes individuals into account, while being guided by broad ethical principles. ${ }^{99}$ Ramp and Bekoff argue that:

[u]nlike the dominant utilitarian approach to conservation, which puts the cost of reaching conservation targets squarely on the shoulders of other animals, a compassionate ethic for conservation brings empathy into decision-making alongside other values. It is not a rights position but, rather, puts forward a scientific and evidence-based conceptual approach that stipulates that conservation initiatives should first do no harm. ${ }^{100}$

In similarity with Earth jurisprudence, compassionate conservation challenges society's anthropocentrism and the exploitative model of human-nature domination. ${ }^{101}$ Unlike Earth jurisprudence, this challenge does not lead to legal interests or legal rights, but to a science-based decision-making paradigm that starts from

94. White (n 88) 391-93; generally, Dalle (n 88); Sherley (n 88) 454; Thiriet (n 88) 163-65, 180-84.

95. Krithika Srinivasan, 'Caring for the Collective: Biopower and Agential Subjectification in Wildlife Conservation' (2014) 32 Environment and Planning D: Society and Space 501, $501,509$.

96. Ibid, 502 .

97. Ibid, 505-06.

98. Ramp and Bekoff (n 16) 325.

99. Ibid.

100. Ibid.

101. Ramp et al (n 2) 308. 
the premise that regulation 'should first do no harm'. This stands in direct contrast to current management approaches, based on sustainable development, which have been criticized for becoming almost synonymous with continual growth and the commodification of nature. ${ }^{102}$

For these reasons, at least one commentator has examined whether sustainable development should be paraphrased as 'living sustainably' and incorporate an ethical dimension, that 'reinvent[s virtue ethics] ... for contemporary life'. ${ }^{103}$ Virtue ethics is a philosophy drawn from the writings of Aristotle and focuses on the morality of people's behaviour. ${ }^{104}$ As a starting point, Aristotle rejected the notion that animals were worthy of direct moral concern, because they lacked rationality. ${ }^{105}$ Yet, Aristotle's philosophies on virtue and teleology are still relevant, combining personal integrity with the notion that entities have value beyond their use to humans. ${ }^{106}$ Empathy, which is a core component of compassionate conservation, derives from these concepts. In an ecological setting, science identifies the purpose of ecosystems, populations and individual entities, as well as the capacity of collectives and individuals within ecosystems to flourish. ${ }^{107}$ Ethics, and more particularly virtue ethics, identifies human qualities, or virtues, which, in a regulatory context, allow entities and collectives to flourish and fulfil their purpose. ${ }^{108}$ Of necessity, this should cause humans to reconsider behaviour and activities, such as land clearing, that elevate human wants at the expense of the environment, including collectives, and/or individual entities.

By focusing on human behaviour, virtue ethics represents a radical departure from current ideals, based on utilitarianism, that target the consequences of an action. The latter has invariably allowed regulators to justify killing animals 'for the greater good if it results in a larger balance of benefits over the detriment of killing'. ${ }^{109}$ As a practical example, utilitarianism justifies killing overabundant noisy miners, bell miners, cockatoos and wombats because it is regarded as an appropriate response to the threats presented by these animals. By way of contrast, virtue ethics impels humans to examine the necessity of killing, the method of killing, whether killing is an effective response, and whether other forms of regulation are feasible and appropriate. It should lead regulators to examine why noisy miners, bell miners, cockatoos and wombats have become invasive and modify human behaviour accordingly. The exhortation from compassionate conservation to 'do no harm' is not merely a call to consider whether the consequences of an action can be justified, but a call to consider how human activities contribute to harm and how to obviate that harm, including at an individual level.

By questioning the welfare burden placed on individual animals, compassionate conservation implicitly critiques the fixation on collectives. Yet, collectives have been the traditional focus of science; hence, to make compassionate conservation

102. United Nations, Sustainable Development, Harmony with Nature, Report of the SecretaryGeneral, A/71/266, 96; Plumwood (n 4) 99-100.

103. John A Vucetich and Michael P Nelson, 'The Infirm Ethical Foundations of Conservation' in Bekoff (n 1) 9, 18.

104. Ibid, 15.

105. Marc R Fellenz, The Moral Menagerie, Philosophy and Animal Rights (University of Illinois Press, 2007) 92, 98.

106. Ibid.

107. John A Vucetich and Michael P Nelson, 'The Infirm Ethical Foundations of Conservation' in Bekoff (n 1) 18-19.

108. Ibid.

109. Generally, Riley (n 32) 283. 
workable, science also needs to start considering individuals. ${ }^{110}$ To do otherwise not only restricts scientific knowledge and understanding, but also has ethical consequences, because it strengthens the traditional focus on collectives. ${ }^{111}$ At the same time, compassionate conservation does not authorize regulators to ignore ecosystem health, or allow the welfare of individual entities to override other considerations, but it does mean that meaningful regard for individual entities needs to be taken into account as part of management practices. ${ }^{112}$

The discussion should not be taken as a conclusion that Earth jurisprudence and compassionate conservation are consistent in every respect. Notwithstanding the metaphorical call to 'listen to nature's voice', determining the practical ambit of Earth jurisprudence and its relationship to science still remains somewhat elusive. Science-based approaches focus on causative factors and outcomes while Earth jurisprudence also admits moral consideration of the relationship between humans and nature. This potentially creates a tension, not only between scientific and ethical interpretations of the Great Law itself, but also between Earth jurisprudence and compassionate conservation.

Nevertheless philosophies of virtue ethics can draw together the science-based precepts of compassionate conservation and the ethical underpinnings of the Great Law, by acknowledging the need to modify human behaviour, both in its ethical foundations and its practical import. ${ }^{113}$ The differences between compassionate conservation and Earth jurisprudence lie in the method chosen to achieve these objectives, with compassionate conservation being science-based and Earth jurisprudence being legally-based. These differences, however, do not signify that the two approaches are incompatible. Indeed, Earth jurisprudence and compassionate conservation potentially provide a way to synthesize science, law and ethics, commensurate with Berry's hopes that law and ethics would draw upon the other's strengths and compensate for the other's weaknesses. ${ }^{114}$

\section{REDESIGNING REGIMES: INVASIVE SPECIES, EARTH JURISPRUDENCE AND COMPASSIONATE CONSERVATION}

From the discussion thus far, the regulation of invasive species raises many contentious issues, including how regulators perceive environmental harm, the individual versus collective debate and the welfare burden placed on invasive species. Although regulators frequently frame the solution in terms of classifying species as invasive and concentrating efforts on eradication and control, these approaches can be counter-productive because they do not address the heart of the problem, which is how regulators deal with humans and their conflicting views on environmental management.

Conflict may be perceived in terms of human-nature interactions, or in terms of human-human interactions. ${ }^{115}$ Environmental problems, for example, are often disagreements about divergent outlooks on land management practice, engendering a plurality of stakeholders and voices. Lunney points out that humanity has an ethical

110. Liv Baker, 'Why Individuals Matter' in Bekoff (n 1) 159.

111. Ibid.

112. Ramp and Bekoff (n 16) 325-26.

113. Burdon (n 68) 67.

114. Ibid, 3, 5, 8 .

115. Filgueira and Mason (n 16) 200. 
imperative not to 'let our native fauna slide to extinction ... [and to] manage overabundant populations'. ${ }^{116}$ However, while some property holders may see invasive species as a resource; others might regard these species as the cause of environmental degradation; yet again, others might see invasive animals as a symptom of humancreated environmental problems and argue that regulation needs to pay more attention to individual animal wellbeing. ${ }^{117}$ These differing outlooks alter how the problem, and thus the solution, is perceived; where the focus centres on species and their classifications it side-steps the significance of the human element. If the problem, however, were to be recalibrated as a human problem, it becomes clearer that the solution lies in modifying human behaviour, or more specifically, ensuring that human law is consistent with the Great law.

In pondering how this could occur, Cullinan notes that society would need to "refine its ideas about what is "right" and "wrong". ${ }^{118}$ In particular, law and policy based on Earth jurisprudence should draw regimes towards a form of governance that emphasizes 'mutually-beneficial relations' among the Earth community. ${ }^{119}$ Human laws would therefore need to 'listen ... to nature'. ${ }^{120}$ As already indicated, this requires input from science, yet such input alone does not resolve the issue, for science needs to be translated into law and policy. The latter, however, are mired by legal positivism, which traditionally attributes worth to humans and human ideals, isolating regimes from engagement with ethical precepts. ${ }^{121}$ It is at this point, that the Great Law, positioned above human law, can be critical to re-considering the reach of legal positivism, guiding human-nature interactions along more ethical pathways.

In the context of invasive species, this should involve evaluating why species become invasive and, rather than automatically killing animals which have taken advantage of altered environments, listening to the needs of nature in order to redress ecosystem imbalance. Some of the most profound changes would be seen in the classification, and thus treatment, of individual animals and the way regulators conceptualize environmental threats; matters that are also important to the call from compassionate conservation to do no harm.

This exercise does not start from a blank slate. Filgueira and Mason, for example, have surveyed a range of laws applying to mountains, forests and endangered species and have identified regulation that is already commensurate with key tenets of Earth jurisprudence, such as, the interdependency of life. ${ }^{122}$ In an analogous way, Australian policy instruments relevant to invasive species' regulation, broach ethical considerations and refer to the need for holistic regimes where eradication and control measures

116. Daniel Lunney, 'Ethics and Australian Mammalogy: Reflections on 15 Years (1991-2006) on an Animal Ethics Committee' (2012) 34(1) Australian Mammalogy 1, 14.

117. Stuart Harrop categorises conflict problems as problems of human conflict. See, generally, Stuart Harrop, 'Climate Change, Conservation and the Place for Wild Animal Welfare in International Law' (2011) 23(3) Journal of Environmental Law, 441; Anca Vlasopolos, 'Review of Killing Animals (Steve Baker, ed.) (University of Illinois Press, 2006)'. H-Animal, H-Net Reviews (August 2007). Available from https://networks.h-net.org/node/16560/reviews/ 16724/vlasopolos-baker-killing-animals, accessed 18 March 2019.

118. Cormac Cullinan, 'If Nature Had Rights, What Would We Need to Give Up?' in Burdon (n 62) 230, 233-34.

119. Judith E Koons, 'At the Tipping Point: Defining an Earth Jurisprudence for Social and Ecological Justice' (2012) 58 Loyola Law Review 349, 389.

120. Filgueira and Mason (n 16) 198.

121. Burdon (n 68) 63, 65, 66.

122. Filgueira and Mason (n 16) 193, 200. 
are part of broader strategies. ${ }^{123}$ However, as with the laws examined by Filgueira and Mason, objectives in Australian instruments are not supported by targets and performance indicators, hindering laws and strategies from becoming fully operational. ${ }^{124}$ Animal welfare standards are a case in point. Strategies such as the Animal Biosecurity and Welfare Strategic Plan 2013-15 contain broad aspirational statements dealing with animal welfare. ${ }^{125}$ Yet, there is little elaboration as to what this means in practice and how it will be achieved. As a stark illustration, control of foxes in NSW still depends on sodium fluoroacetate (1080), which is promoted as being humane, notwithstanding the fact that its use remains contentious. ${ }^{126}$

Indeed, the use of lethal methods is particularly controversial and represents an area of invasive species regulation where compassionate conservation can be helpful. Primarily, its scientific underpinnings can identify problems and outcomes across a range of measures, setting limits on use of lethal control. ${ }^{127}$ Commentators have already turned their minds to this question, devising critical safeguards for regimes. ${ }^{128}$ Mellor and Littin, for example, provide that, at the very least, regulators need to be satisfied that interventions are necessary and justifiable and have also examined whether non-lethal methods are available. ${ }^{129}$ Others note that lethal control requires a high threshold of justification that takes into account the lives and wellbeing of both target and non-target animals. ${ }^{130}$ Moreover the justification for lethal measures

123. For example, the Natural Resource Management Ministerial Council, Australian Pest Animal Strategy - A National Strategy for the Management of Vertebrate Pest Animals in Australia, Commonwealth of Australia (2007). 2, 3, where the strategy contains references to animal welfare without indicators or detail; pages 1,4 , and 7 contain detail on pest animal management being part of broader strategies but with insufficient detail.

124. Alex Bruce, Animal Law in Australia (LexisNexis, 2nd edn 2018) 240.

125. NSW Department of Primary Industries Livestock Health and Pest Authorities NSW, The Animal Biosecurity and Welfare Strategic Plan 2013-15, NSW Government (2013), pages 2 and 5 and the general tenor of the plan that focuses on diseases of farm animals.

126. Sherley (n 88) 449 and 454; NSW Scientific Committee, Final Determination on 1080 Poison Baiting Used for the Control of Vertebrate Pest Animals - Rejection of Key Threatening Process Listing (2008) para. 3.

127. Michelle L Lute, Carlos David Navarrete, Michael Paul Nelson and Meredith L Gore, 'Moral Dimensions of Human-Wildlife Conflict' (2016) 30(6) Conservation Biology 1200, 1200.

128. For example, Paula-Marie Lewis, Georgette Leah Burns and Darryl Jones, 'Response and Responsibility: Humans as Apex Predators and Ethical Actors in a Changing Societal Environment' (2017) 12 Food Webs 49, 51; Daniel Lunney, Jack Baker, Alison Matthews, Kelly Waples, Chris Dickman and Hal Cogger, 'Overabundant Native Vertebrates in New South Wales: Characterising Populations, Gauging Perceptions and Developing an Ethical Management Framework' in Daniel Lunney, Peggy Eby, Pat Hutchings and Shelley Burgin (eds), Pest or Guest (Royal Zoological Society of New South Wales, 2007) 158, 169.

129. David M Mellor and Kate E Littin, 'Killing Pest Animals - Some Ethical Issues in Solutions for Achieving Human Vertebrate Pest Control' in Bidda Jones (ed), Proceedings of the 2003 Australia Scientific Seminar, Canberra (RSPCA, 2003) 44, 44. Available from www.rspca.org.au/sites/default/files/website/The-facts/Science/Scientific-Seminar/2003/ SciSem2003-Proceedings.pdf, accessed November 2014.

130. James C Russell, Holly P Jones, Doug P Armstrong, Franck Courchamp, Peter J Kappes, Philip J Seddon, Steffen Oppel, Mark J Rauzon, Phil E Cowan, Gérard Rocamora Piero Genovesi, Elsa Bonnaud, Bradford S Keitt, Nick D Holmes and Bernie R Tershy, 'Importance of Lethal Control of Invasive Predators for Island Conservation' (2016) 30(3) Conservation Biology 670, 670; Ngaio J Beausoleil, 'Balancing the Need for Conservation and the Welfare of 
must be supported by strong environmental criteria which make it feasible that interventions will reverse environmental harm. ${ }^{131}$ Finally, it almost goes without saying that regulators need to choose the most humane methods and if no such methods are available, they should devise alternative processes. ${ }^{132}$

In the case of overabundant birds, such as noisy miners and bell birds, 'doing no harm' would question utilitarian approaches that justify killing where benefits elsewhere are said to outweigh the harm to noisy miners and bell miners. Moreover, an Earth jurisprudence approach, relying on scientific evidence to find nature's voice, would question wholesale killing and instead, consider long-term solutions such as prohibiting clearing of low-lying vegetation, forbidding destruction of canopy cover, encouraging re-vegetation and undertaking selective weed removal.

From a practical point of view, eradication and control are also less likely to be successful than measures implemented to prevent degradation of ecosystems in the first place; they are also likely to be less successful than measures undertaken to restore ecosystems that take into account habitat and resource preferences of individual species, particularly those at risk, or those that are starting to become invasive. ${ }^{133}$ However, preventing ecosystem degradation frequently involves prohibiting or strictly controlling land clearance, something that in Australia is very contentious. ${ }^{134}$ The question of what amounts to appropriate restoration of ecosystems could also prove challenging as it focusses on providing habitat and resources for an array of species, rather than promoting popular cultivars. ${ }^{135}$ To be effective these approaches entail multifaceted solutions, that of necessity require uniting landholders, nursery vendors and other stakeholders. ${ }^{136}$ They also require a strong knowledge-base and continual scrutiny of the effectiveness of regimes, underpinned by 'clearly defined objectives ... monitoring and audit procedures', perspectives that are not always found in environmental regulation. ${ }^{137}$

In truth, governments have been criticized for their frequent focus on short-term, 'crisis' measures, which do not provide long-term solutions to what, effectively,

Individual Animals' in MC Appleby, DM Weary and P Sandoe (eds), Dilemmas in Animal Welfare (CABI International, 2014) 124; CR Dickman and Daniel Lunney, 'Last Howl of the Dingo: the Legislative, Ecological and Practical Issues Arising from the Kill-or-Conserve Dilemma' in CR Dickman and Daniel Lunney (eds), A Symposium on the Dingo (Royal Zoological Society of New South Wales, 2001) 95, 103-05.

131. Russell et al, ibid, 670.

132. Beausoleil (n 130) 124; Werner Scholtz, 'Killing Them Softly? Animal Welfare and the Inhumanity of Whale Killing' (2017) 20(1) Journal of International Wildlife Law and Policy $27,37$.

133. Rodewald and Arcese (n 42).

134. For example, NSW Rural Team, 'Questions Raised About Landmark Changes to NSW Land Clearing Laws', ABC News, 28 December 2016, available from www.abc.net.au/news/ rural/2016-12-28/landmark-changes-to-nsw-land-clearing-laws/8123918, accessed 18 March 2019; also, generally, Robyn Bartel and Nicole Graham, 'Property and Place Attachment: A Legal Geographical analysis of Biodiversity law Reform in New South Wales' (2016) 54(3) Geographical Research 267.

135. Burgin (n 13) 674.

136. Catterall (n 37).

137. Wardell-Johnson and Lynch (n 44) 247; R Warburton and B G Norton, 'Towards a Knowledge-Based Ethic for Lethal Control of Nuisance Wildlife' (2009) 73(1) Journal of Wildlife Management 158, 162. 
are chronic problems. ${ }^{138}$ This not only leads to lack of long-term reduction in population numbers of invasive species, but also side-steps engagement with the theoretical and ethical foundations of humanity's relationship with the environment. ${ }^{139}$ However, while humans have the potential to dominate ecosystems, they also have the capacity to design ethical regimes. ${ }^{140}$ The commonalities that weave through the suggestions for reform rest on how management decisions are made and the moral probity of regimes, dilemmas that place humans at the forefront. Earth jurisprudence and compassionate conservation provide a means of incorporating these considerations into decision-making.

\section{CONCLUSION}

Sustainable development, the predominant environmental decision-making paradigm, identifies links between invasive species and threats to biodiversity that, in accordance with utilitarian philosophies, call for eradication and control of invasive species. At the same time, control and eradication raise practical and ethical considerations that are unevenly addressed by current regulation. ${ }^{141}$ In particular, authorities rarely question why lethal methods are a first response, and why the role of humans in encouraging species to become invasive is often overlooked. These regulatory gaps are indicative of humanity's inattentiveness to environmental problems it has created, leading to discordant relationships with the Earth and its ecological systems. For these reasons, Earth jurisprudence and compassionate conservation emphasize that humans need to start listening to nature. From a legal perspective this entails paying more than lip service to the interdependent relationship of humans with the Earth and ensuring that human laws are consistent with the Great Law of Earth jurisprudence. Although, for some, the Great Law derives from the universe itself; for others it is reflected, more pragmatically, in accepted and broadly-based scientific principles. These principles will continuously be developed and refined; however, the cornerstone lies in accepting the interconnectedness of life on Earth and the fact that humans are only one element in this web. Regulators, therefore, need to take heed of scientific knowledge, including those parts that critique current approaches, and use it to underpin the Great Law.

Indeed, ideals flowing from Earth jurisprudence and compassionate conservation tacitly acknowledge that society cannot resolve environmental problems with the same techniques and pathways that created those problems. Instead of attempting to redecorate and dominate nature, society needs to work with nature, aligning law and policy with nature's laws. Accordingly, humans need to modify their own behaviour and engage with frameworks presented by emerging paradigms such as Earth jurisprudence and compassionate conservation that place humans at the forefront of resolving environmental problems.

138. Department of the Environment Food and Rural Affairs (DEFRA), Review of Non-Native Species Policy Report of the Working Group (DEFRA Publications, 2003) 21-22; Environmental Law Institute, Status and Trends in State Invasive Species Policy: 2002-2009 (ELI, 2010) 17; Ramp et al (n 2) 308-09.

139. Generally, Riley (n 32) 276.

140. Lewis, Burns and Jones (n 128) 49, 51.

141. Vucetich and Nelson (n 103) 15. 